\title{
Effects of dietary concentrates on the metabolism of energetic compounds in the portal-drained viscera (PDV) and in the liver in lactating dairy cows
}

\author{
EA Casse, $\mathrm{H}$ Rulquin \\ INRA, station de recherches sur les Vaches laitières, Saint-Gilles, 35590 L'Hermitage, France
}

Portal-drained viscera (PDV) and hepatic metabolism of glucose, L-lactate, urea, D- $b$ hydroxybutyrate $\left(\mathrm{DbOHC}_{4}\right)$ and nonesterified fatty acids (NEFA) were studied in 3 multicatheterized (Huntington et al, 1989) dairy cows at 20 wk of lactation.

Milked animals were fed a basal diet consisting of a DM basis of $30 \%$ dehydrated alfalfa, $40 \%$ corn silage and $30 \%$ concentrate. Two sources of concentrate were compared: a concentrate (FG) rich in rapidly degradable glucide $(79 \%$ wheat) and a concentrate (SF) rich in slow degradable fibre $(82.5 \%$ soya hulls). Each animal successively received the 2 diets for $15 \mathrm{~d}$ in a reversal design. Simultaneous blood samples (12 s/cow) were withdrawn every $h$ during the post-prandial period from the aorta and from the hepatic and portal veins. Plasma flows were determined by the PAH dye dilution method.

DOM intake and milk yield tended to increase slightly with the SF diet (11.3 and $12.5 \mathrm{~kg} \mathrm{DOM} / \mathrm{d}$ and 23.0 and $24.3 \mathrm{~kg}$ milk/ $\mathrm{d}$ for diets $\mathrm{FG}$ and SF respectively). Comparison of metabolite flux between diets was related to digestible organic matter intake and showed variations in the resulting tissue balances. Diet SF increased hepatic production of glucose and urea which both tended to be more utilized by the PDV; $\mathrm{DbOHC}_{4}$ production increased in both tissues. This stimulation in energetic compound production is associated with less hepatic extraction of precursors such as $\mathrm{L}$ lactate and NEFA.

In conclusion, degradable fibre diets seemed to permit a slightly higher milk production associated with more energetic compounds produced in splanchnic tissues. The higher rate of fermentation with the FG diet could result in a less efficient use of energy. Volatile fatty acid and amino acid flux measurements could confirm or disprove this.

Huntington GB, Reynolds C, Stroud B (1989) J Dairy Sci 72, 1583-1595

Table I. Effect of the type of concentrate on the net flux of some compounds in the portal drained viscera (PVD) and in the liver.

\begin{tabular}{|c|c|c|c|c|c|c|}
\hline \multirow[t]{2}{*}{ Net flux in treatments } & \multicolumn{3}{|c|}{ Liver } & \multicolumn{3}{|c|}{$P D V$} \\
\hline & $F G$ & $S F$ & $S D$ & $F G$ & $S F$ & $S D$ \\
\hline Glucose $(\mathrm{mmol} / \mathrm{kg}$ DOM $)$ & $726.5^{a}$ & $897.2^{b}$ & 19.7 & $-103.5^{a}$ & $-258.2^{b}$ & 27.2 \\
\hline Lactate $(\mathrm{mmol} / \mathrm{kg} \mathrm{DOM})$ & -336.3 & -316.8 & 21.7 & 317.5 & 403.7 & 23.3 \\
\hline $\mathrm{DbOHC}_{4}(\mathrm{mmol} / \mathrm{kg} \mathrm{DOM})$ & $639.3^{\mathrm{a}}$ & $714.5^{\mathrm{b}}$ & 10.5 & 593.2 & 643.7 & 84.5 \\
\hline $\mathrm{NEFA}(\mathrm{mmol} / \mathrm{kg} \mathrm{DOM})$ & -36.8 & -31.6 & 4.9 & -7.6 & -2.6 & 2.8 \\
\hline Urea $(\mathrm{g} / \mathrm{kg}$ DOM) & 47.8 & 55.5 & 2.7 & -9.0 & -17.7 & 3.2 \\
\hline
\end{tabular}

